\title{
An Analysis of the Progress of Financial Inclusion in India
}

\author{
Sushila Jaglan \\ Assistant Professor, Bhagat Phool Singh Institute of Teacher Training and Research, \\ Bhagat Phool Singh Mahila Vishwavidyalaya, Sonipat, Haryana, India.
}

CITATION: Jaglan, Sushila (2020), "An Analysis of the Progress of Financial Inclusion in India", MERC Global's International Journal of Management, Vol. 8, Issue 3, pp. 103-115.

ARTICLE HISTORY: Submitted: March 22, 2020, Revision received: April 29, 2020, Accepted: May 18, 2020

\section{ARTICLE TYPE: Research paper}

\begin{abstract}
Financial inclusion is increasingly being recognised as a key driver of economic growth and poverty alleviation the world over (World Bank). Financial inclusion in India is much older than the formal adoption of the term. Financial inclusion in India has been started even before independence. Since independence, the Reserve Bank of India and the Government of India (GOI) has been making efforts to enhance financial inclusion in the country. Some of these measures include the creation of an extensive network of rural cooperative banks in the 1950s, the formation of State Bank of India in 1955, nationalisation of life insurance companies in 1956, nationalisation of banks in 1969 and 1980, lead bank scheme in 1970, nationalisation of general insurance companies in 1972, the establishment of Regional Rural Banks in 1975, introduction of Self Help Group-Bank Linkage program in 1992, creation of 'no-frill' or 'zero balance savings account' for the common man (2005), PradhanMantri Jan DhanYojana (2014), MUDRA bank (2015), Stand up India (2016) and many more. Further, RBI has also prepared the National Strategy for Financial Inclusion 2019-24. The present study provides an overview of the efforts of GOI and RBI to enhance financial inclusion in India. It further analyses the progress of financial inclusion in India in terms of access and usage of the last 10 years, i.e. from 2010 to 2019 and provides an insight into the National Strategy for Financial Inclusion in India 2019-24.
\end{abstract}

KEYWORDS: Financial inclusion, Analysis of progress, RBI, Banking outlets, Indicators, Bank wise ATMs, National strategy for financial inclusion.

\section{BIBLIOGRAPHY}

1. Altaf, Nufazil (2019), "Financial Slack and Firm performance- Evidence from India", MERC Global's International Journal of Management, Vol. 7, Issue 1, pp. 113-119.

2. Ambarkhane, Dilip; Singh, Ardhendu Shekhar and Venkataramani, Bhama (2016), "Measuring financial inclusion of Indian states", International Journal of Rural Management, Vol. 12, Issue 1, pp. 72-100.

3. Barik, Rajesh and Sharma, Pritee (2019), "Analysing the progress and prospects of financial inclusion in India", Journal of Public Affairs, Vol 19, Issue 4, pp. 1-6.

4. Deepti, N. S. and Vaidhyasubramaniam, S. (2018), "Measure of Index on Financial Inclusion in India.", International Journal of Pure and Applied Mathematics, Vol. 119, Issue 10, pp. 1147-1454.

5. Financial Inclusion (n.d.), Department of Financial Services, Ministry of Finance, Government of India, available at: https://financialservices.gov.in/financial-inclusion, accessed on April 1, 2020.

6. Goel, Sweta and Sharma, Rahul (2017), "Developing a financial inclusion index for India", Procedia Computer Science, Vol. 122, pp. 949-956.

7. How to Measure Financial Inclusion, (n.d.), World Bank, available at: https://www.worldbank.org/en/topic/financialinclusion/brief/how-to-measure-financial-inclusion, accessed on March 1, 2020.

8. Important Schemes (n.d.) Department of Financial Services, Ministry of Finance, Government of India, accessed on March 1, 2020. 
9. Inoue, Takeshi (2019), "Financial inclusion and poverty reduction in India", Journal of Financial Economic Policy, Vol. 11, Issue 1, pp. 21-33.

10. Iqbal, Badar Alam and Sami, Shaista (2017), "Role of banks in financial inclusion in India", Contaduría y Administración, Vol. 62, Issue 2, pp. 644-656.

11. Jose, Tojo (2016), Financial inclusion measures in India - Indian, Indian Economy, September 21.

12. Kuppan, S. (2012), "Financial Inclusion" Management Accountant, New Delhi, Vol. 47, Issue 1, pp. 1214.

13. National Strategy for Financial Inclusion (n.d.). Drishti IAS, available at https://www.drishtiias.com/daily-updates/daily-news-analysis/national-strategy-for-financial-inclusion, accessed on March 4, 2020.

14. Neelam (2017), List of Government Schemes for Financial Inclusion in India, India Study Channel, October 13.

15. Rajput, Namita and Oberoi, Shelly (2015), "Reaching the Unreached: Financial Inclusion in India-A Study", Section 1, pp. 25-37.

16. Rao, K. S. (2018), Financial Inclusion in India: Progress and prospects, Ideas for India, July 11, available at: $\quad$ http://www.ideasforindia.in/topics/money-finance/financial-inclusion-in-india-progress-andprospects.html.

17. Reserve Bank of India - Annual Report (2010, August 24), Reserve Bank of India, available at: https://m.rbi.org.in/Scripts/AnnualReportPublications.aspx?Id=1259.

18. Reserve Bank of India - Annual Report (2011, August 25), Reserve Bank of India, available at: https://m.rbi.org.in/Scripts/AnnualReportPublications.aspx?Id=1259.

19. Reserve Bank of India - Annual Report (2012, August 23), Reserve Bank of India, available at: https://m.rbi.org.in/Scripts/AnnualReportPublications.aspx?Id=1259.

20. Reserve Bank of India - Annual Report (2013, August 22), Reserve Bank of India, available at: https://m.rbi.org.in/Scripts/AnnualReportPublications.aspx?Id=1259.

21. Reserve Bank of India - Annual Report (2014, August 21), Reserve Bank of India, available at: https://m.rbi.org.in/Scripts/AnnualReportPublications.aspx?Id=1259.

22. Reserve Bank of India - Annual Report (2015, August 27), Reserve Bank of India, available at: https://m.rbi.org.in/Scripts/AnnualReportPublications.aspx?Id=1259.

23. Reserve Bank of India - Annual Report (2016, August 29), Reserve Bank of India, available at: https://m.rbi.org.in/Scripts/AnnualReportPublications.aspx?Id=1259.

24. Reserve Bank of India - Annual Report (2017, August 30), Reserve Bank of India, available at: https://m.rbi.org.in/Scripts/AnnualReportPublications.aspx?Id=1259.

25. Reserve Bank of India - Annual Report (2018, August 29), Reserve Bank of India, available at: https://m.rbi.org.in/Scripts/AnnualReportPublications.aspx?Id=1259.

26. Reserve Bank of India - Annual Report (2019, August 29), Reserve Bank of India, available at: https://m.rbi.org.in/Scripts/AnnualReportPublications.aspx?Id=1259.

27. Reserve Bank of India - Bankwise ATM/POS/Card Statistics (n.d.), available at: https://www.rbi.org.in/Scripts/ATMView.aspx, accessed on March 3, 2020.

28. Reserve Bank of India - Handbook of Statistics on Indian Economy (n.d.), available at: https://www.rbi.org.in/scripts/AnnualPublications.aspx?head=Handbook\%20of\%20Statistics\%20on\%20I ndian\%20Economy, accessed on March 19, 2020.

29. Sarma, M. (2008), "Index of financial inclusion", No. 215, Working paper.

30. Sharma, Anupama and Kukreja, Sumita (2013), "An analytical study: Relevance of financial inclusion for developing nations", International journal of engineering and science, Vol. 2, Issue 6, pp. 15-20.

31. Sharma, Dipasha (2016), "Nexus between financial inclusion and economic growth." Journal of Financial Economic Policy, Vol. 8, Issue 1, pp. 13-36.

32. Swain, B. K. (2012), "Towards Financial Inclusion in India", Journal of Rural Development, Vol. 31, Issue 1, pp. 129-130. 